\title{
Analysing ICT Economic Impact in Vietnam
}

\author{
Dang Thi Viet Duc ${ }^{1} \&$ Dang Huyen Linh $^{2}$ \\ ${ }^{1}$ Posts and Telecommunications Institute of Technology, Hanoi, Vietnam \\ ${ }^{2}$ Vietnam Institute for Development Strategies, Ministry of Planning and Investment, Hanoi, Vietnam \\ Correspondence: Dang Thi Viet Duc, Posts and Telecommunications Institute of Technology, Km 10, Nguyen Trai \\ street, Hanoi, Vietnam. Tel: 84-91-493-2612. E-mail: ducdtv@ptit.edu.vn
}

Received: July 20, 2020

doi:10.5430/rwe.v11n5p34
Accepted: August 21, 2020

Online Published: September 3, 2020

\begin{abstract}
This article applied the input-out table (IO) analysis to estimate the linkages of ICT sectors to the Vietnam economy. In this article, the shared output requirement of ICT sectors is analysed to the multiplier effect, inter-sector feedback effect, and spillover effect. The research also examines the induced increase of ICT's output to the final demand of ICT sectors and non-ICT sectors. The results show that although the impact of the domestic ICT sectors in the Vietnam economy increases through time, it is generally not outstanding in comparison with other sectors. The ICT manufacturing sector is rather self-sufficient, stimulating import rather than added value for the domestic economy. From both the intermediate and final demand inducement, ICT media, content and ICT services sectors reveal their significant diffusion and critical inter-sector relationship with other ICT and non-ICT sectors in the economy. The paper also provides policy implications for the future development of ICT in Vietnam.
\end{abstract}

Keywords: ICT, economic impact, IO, forward linkage, backward linkage, output multiplier, input multiplier, import multiplier, value-added multiplier, inter-sector relationship, spillover effect, Vietnam

JEL Classification: D57, R10, C67, R19, O00, B40

\section{Introduction}

Information and Communication Technology (ICT) has become the enabler of the economy over the past few decades. The widespread use of telecommunications, the Internet, mobile networks, the development of new technologies such as the Internet of Things (IoT), cloud computing, big data science, and artificial intelligence (AI) in business shows the diffusion of ICT on economic activities. ICT exists in the operation of every business. This fact has spurred research on ICT and its economic impact in countries.

The impact of ICT on the economy has been explained through some theories, of which two notably theories are General Purpose Technology (GPT) and Technological Paradigm theory. General-purpose technology theory was developed by some neoclassical economists such as Helpman (1998), Bresnahan and Trajtenberg (1992), considering ICT as a general-purpose technology. Unlike conventional technologies, general-purpose technology has three distinctive characteristics: pervasiveness, improvement, and innovation spawning. Technology paradigm theory associates ICT with the concept of technology paradigm (Dosi, 1982; Perez, 1983, 2004; Freeman, 2005). A technological paradigm includes a set of basic technologies created and directed by specific principles and practical rules. The basic technological group as a "paradigm" must have a breakthrough effect, not only in terms of technical aspects but also in the structure of the organization and management which constitutes a revolution that changes the whole logic of production and economy. Both general purpose technology and technological paradigm theory affirm the broad and spillover effect of ICT in the economy. Therefore, assessing the impact of ICT on the economy must always take into account the spillover effect of ICT on other economic sectors. Besides, both theories confirm the process, the multidimensional influences of ICT on the economy as well as the conditions to realize these economic influences. This means that the level of impact of ICT should not be the same among different countries.

Many empirical studies have been carried out to assess the importance of ICT to the economy in different countries. ICT has been shown to have a positive effect on economic growth (Daveri, 2000; Niebel, 2014; Karlsson and Liljevern, 2017) and labour productivity (Schreyer, 2000; Kegels, van Overbeke, and van Zandweghe, 2002; Heshmati and Wang, 2010). When considering the spillover effect of the ICT sector, many quantitative studies confirm the distinguished role of the ICT sector compared to other sectors in the economy (India Ministry of 
Communications and Information Technology, 2005; Heng and Thangavelu, 2010; Kretschmer, 2012). However, in many other cases, ICT does not exhibit a unique spillover effect as suggested by the theories (Bazzazan, 2009; Keček, Hrustek, and Dušak, 2016; Irawan, 2013). Impact assessment studies are mainly conducted for developed countries. Researches for developing countries are limited, partly because the economic impact of ICT in these countries may not be outstanding and partly because data is unavailable there.

In Vietnam, information and communication technology has been officially considered as a key for socio-economic development since 1993 through the Government's Resolution No. 49/CP on "information technology development in Vietnam in the 1990s". Up to now, Vietnam has consistently affirmed that ICT is indispensable for economic development. However, quantitative assessments of the impact of ICT on the Vietnam economy are rare. Only two empirical works on such effort are found, both of which are of limitations. Asian Productivity Organization [APO] (2018) uses growth accounting to show the contribution of ICT capital and labour to national economic growth and labour productivity. Duc and Linh (2018) use IO method to analyse ICT's multiplier impact on the Vietnam economy. APO (2018) only estimates the direct impact of ICT in the economy while Duc and Linh (2018) have limitations in up-to-date data and only reach the initial impact indicators of ICT in Vietnam.

This article applied the input-out table (IO) analysis to estimate the linkage of ICT sectors to the economy. In this article shared output requirement of ICT sectors is analysed to the multiplier effect, inter-sector feedback effect, and spillover effect. The research also examines the induced increase of ICT's output to the final demand of ICT sectors and other non-ICT sectors. This article based its calculation on three IO tables, among which two tables, i.e. IO2007, IO2012, are collected from General Statistics Office (GSO) of Vietnam. The Vietnam IO table 2016 was updated from data on enterprise survey, export, import, and Household Living Standards Survey (VHLSS) of Vietnam GSO. After that, the Ras method was used to balance the gross output and gross input of the input-output framework. This entails adjusting both accounts proportionately based on their technical coefficient share ratios on both input and output sides (Lahr and de Mesnard, 2004; Miller and Blair, 2009; Trinh and Phong, 2013; Trinh, Phong, and Quoc, 2018).

The structure of this article is as follows. After the introduction, the second part of the paper provides an overview of the policy and current situation of Vietnam's ICT sectors. Section 3 presents the research methodology, which is followed by the research results in section 4 . Section 5 is the conclusion of the paper. On the one hand, this paper contributes to the literature of ICT economic impact studies in general, especially in the case of developing countries. On the other hand, it is a rare empirical study of the economic impact of ICT in Vietnam, a country that has been advocating ICT for economic development for many years but its impact has not been studied.

\section{Overview of ICT Development Policy and Situation in Vietnam}

The policy on information technology has been formulated since the Government's Resolution No. 49/CP in 1993 on information technology development in Vietnam (Government of Vietnam, 1993). Directive No.58-CT/TW in 2000 of the Central Committee of the Communist Party of Vietnam (Vietnam Communist Party Central Committee 2000) is often considered the most significant guiding document on ICT development in Vietnam because it is issued by the highest level of the political system of Vietnam and also it shows a broader view of the position and the role of ICT in economic development. In 2010, the Prime Minister signed Decision 1755/QD-TTg approving the Project "Bringing Vietnam to soon become a strong country in ICT" which emphasized the determination of the Vietnam government to develop the ICT sector.

From Directive 58-CT/TW up to now, Vietnam's ICT development model has been stably based on four main pillars: ICT Application, ICT Infrastructure, ICT Human Resources, and ICT Industry. The document indicates Vietnam's opinion on ICT: (a) consider ICT to be the most important tool to realize the millennium goals, step by step forming an information society which should shorten the process of industrialization and modernization of the country; (b) consider ICT as a key economic sector, which is with priority in respect to government support; (c) prioritize the development of information and communication infrastructure, which supports ICT applications in all sectors of society; (d) develop skilled human resources, quickly restructure the human resource in the direction of rapidly increasing the proportion of knowledgeable human resources; strongly develop the national technological capacity. In about 25 years, the Vietnam government has launched many different periodical plans to direct the development of ICT.

Vietnam's ICT sector relies heavily on state investment under national ICT development programs and projects (state investment accounts for about 60-70\% of the total investment in ICT). Total ICT investment increased rapidly from 2000 to 2010 and then gradually decreased from 2011 to 2018 (see Figure 1). The ICT investment proportion in the total investment of the whole economy continuously decreased in the period 2000-2018. In 2000, investment in the 
ICT sector accounted for 5\% of total economic investment. This figure was stable at about $3.6 \%$ from 2005 to 2010 and then plummeted to only $1.38 \%$ in 2018 . Thus, although the policy documents affirmed that ICT is a key economic sector, investment capital has decreased sharply in recent years.

In terms of gross domestic products (GDP), the ICT sectors' contribution to the total GDP of the economy has increased over the years. In 2000, ICT contributed 3.5\% of Vietnam's GDP. In 2018, the figure reached 5.6\%. Despite the gradual increase, ICT is still a modest economic sector among 19 sectors listed by the General Statistics Office of Vietnam. However, to correctly assess the impact of the ICT sector in the economy, it is necessary to consider the spillover effect of ICT on other economic sectors.

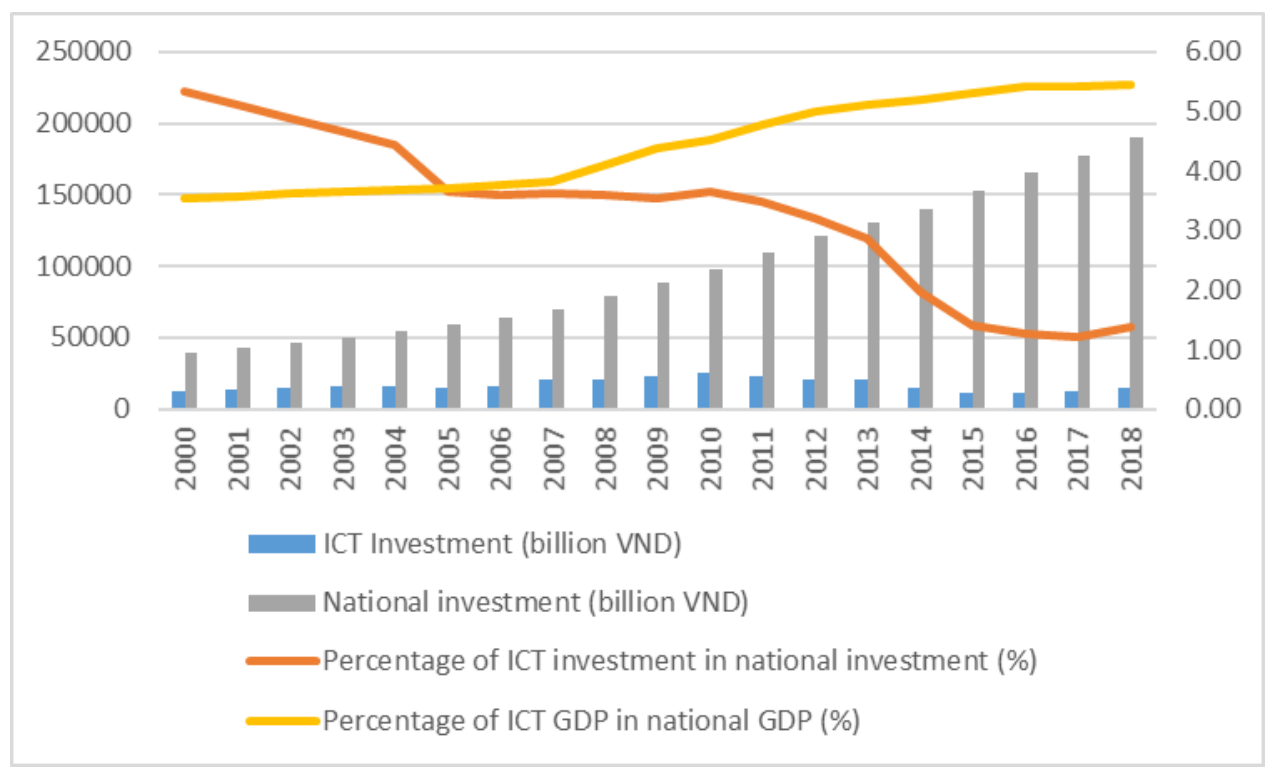

Figure 1. Vietnam ICT investment and GDP (2010 constant price)

Source: GSO, 2019

International development indices allow comparing the situation of Vietnam ICT sector with that of other countries in the world. The World Economic Forum's Technology Readiness Index (NRI) examines the extent of ICT's influence on a country's competitiveness through three component indicators: (1) ICT development environment (market, politics, policy, and infrastructure), (2) The readiness of socio-economic actors (individuals, businesses and governments) to use ICT, (3) The level of ICT use of entities in the economy. Vietnam's rank from 2012 to 2016 is rather stable. In 2016, Vietnam achieved an average score of 3.9/10 and ranked 79th out of 139 countries (World Economic Forum [WEF], 2017). ITU's Information Technology Development Index (IDI) measures development in both developed and developing countries and assesses progress in narrowing the digital gap. IDI is divided into 3 sub-indexes including Access, Use, and Skills. Vietnam's IDI rank has not improved in recent years with rank 102/167 and 108/176 in 2015 and 2017, respectively (International Telecommunication Union [ITU], 2019). Among Southeast Asian countries, Vietnam's rank is higher than Lao, Cambodia, Myanmar, and Indonesia while lower than Singapore, Malaysia, Thailand, and Philippines.

\section{Methodology}

Leontief (1986) developed and presented input-output models as quantitative economic techniques for economic analysis. Input-output tables record transactions between economic sectors, each producing a product and at the same time, consuming products from other industries.

The basic relationship of W. Leontief takes the form:

$$
X=(I-A)^{-1} Y
$$

Where: $\mathrm{X}$ is a vector of gross output, $I$ is an identity matrix, $A$ is a matrix of intermediate input, elements of this matrix are mixed of import products and domestic products, $Y$ is a vector of final demand that includes final 
consumption, gross capital formation, the export of goods and services and negative of import of goods and services. Equation (1) presents the input-output table with a competitive-import type. To further clarify the inter-industry relationship and the extent of spread from the final demand to output and value added, the input-output table needs to move to the input-output table with a non-competitive type. So, the standard Leontief equation has a non-competitive form:

$$
X=\left(I-A^{d}\right)^{-1} Y^{d}
$$

In this equation, the intermediate input matrix $\left(A^{d}\right)$ includes only domestic products, $Y^{d}$ presents domestic final demand, and the negative column import does not appear in the framework.

Backward and forward linkages:

Put $B=\left(I-A^{d}\right)^{-1}$

The backward linkage (output multiplier) and forward linkage (input multiplier) are defined as follows:

Backward Linkage: $\quad B_{j}=\sum_{i} B_{i j}$

It refers to the expansion of an industry when using other industry products as inputs.

And forward linkage:

$$
B_{i}=\sum_{j} B_{i j}
$$

It indicates the level of production depending on the input of other sectors.

Guo and Hewings (2001) argued that increased backward linkage will generate greater demand for inputs by other industry and increased forward linkage will lead to changes in output sensitivity in other sectors. Accordingly, the power of dispersion index (P) and the sensitivity for dispersion (S) of each sector are determined as below:

Power of dispersion index of sector $\mathrm{j}: \quad P_{j}=B_{j}\left(n / \sum_{j} B_{i j}\right)$

Sensitivity for dispersion index of product i: $\quad S_{i}=B_{i}\left(n / \sum_{i} B_{i j}\right)$

Inter-sector analysis

To analyse the relationship between the ICT sectors and the rest of the economy (non-ICT sectors), IO inter-sector analysis was applied. Matrix A is subdivided into sub-matrices for ICT (r) and the rest of the economy (s) as follows:

$$
A=\left[\begin{array}{ll}
A_{r r}^{d} & A_{r s}^{d} \\
A_{s r}^{d} & A_{s s}^{d}
\end{array}\right]
$$

Put:

$$
B=\left(I-A^{d}\right)^{-1}=\left[\begin{array}{ll}
B_{r r}^{d} & B_{r s}^{d} \\
B_{s r}^{d} & B_{s s}^{d}
\end{array}\right]
$$

$\mathrm{B}_{\mathrm{ij}}{ }^{\mathrm{d}}$ is a sub-matrix of the Leontief inverse matrix that represents an inter-sector relationship.

$$
X=\left[\begin{array}{ll}
B_{r r}^{d} Y_{r r}^{d}+B_{r s}^{d} Y_{s r}^{d} & B_{r s}^{d} Y_{s s}^{d}+B_{r r}^{d} Y_{r s}^{d} \\
B_{s r}^{d} Y_{r r}^{d}+B_{s s}^{d} Y_{s r}^{d} & B_{s s}^{d} Y_{s s}^{d}+B_{s r}^{d} Y_{r s}^{d}
\end{array}\right]
$$

According to Miyazawa (1976), Sonis and Hewing (1993), matrix B can be decomposed as follows:

$$
\begin{aligned}
& B_{r r}=\left(I-A_{r r}-A_{r s}\left(I-A_{r r}\right)^{-1} A_{s r}\right) \\
& B_{s s}=\left(I-A_{s s}-A_{s r}\left(I-A_{s s}\right)^{-1} A_{r s}\right)
\end{aligned}
$$




$$
\begin{aligned}
& B_{r s}=B_{s s} A_{r s}\left(1-A_{s s}\right)^{-1} \\
& B_{s r}=B_{s s} A_{s r}\left(1-A_{r r}\right)^{-1}
\end{aligned}
$$

For this reason, we can define the three constituent elements in the above formula as follows:

Multiplier effect $\left(I-A_{r r}\right)^{-1}$,

Inter-sector feedback effect $B_{r r}-\left(I-A_{r r}\right)^{-1}$ and

Spillover effects $B_{s r}$ and $B_{r s}$.

From (1) and (7) we have

$$
\begin{aligned}
& \Delta X^{s}=\left(I-A_{s s}\right)^{-1} A_{s r} \Delta X^{r} \\
& \Delta X^{r}=\left(I-A_{r r}\right)^{-1} A_{r s} \Delta X^{s}
\end{aligned}
$$

Relations (9) and (10) indicate that a change of a sector or a sector group will lead to a change of all other sectors of the economy. Increasing output of sector group $\mathrm{r}(\mathrm{s})$ will lead to a change of sector group $\mathrm{s}(\mathrm{r})$ as $=\left(I-A_{s s}\right)^{-1} A_{s r}$ and $\left(I-A_{r r}\right)^{-1} A_{r s}$

From the general relationship of Leontief, we can calculate the diffusion effect of the final demand through production value to the value added of sector group $r$ and $s$ :

$$
V_{R}, V_{S}=\left(v_{r}, v_{s}\right) X=\left(v_{r}, v_{s}\right)\left[\begin{array}{ll}
X_{r r} & X_{r s} \\
X_{s r} & X_{s s}
\end{array}\right]
$$

Where $X_{r r}$ is the output of region $\mathrm{r}$ that is formed by the final demand product by itself; $X_{r S}$ is the output of region $\mathrm{r}$ induced when region s uses products of region $\mathrm{r}$. The same goes for $X_{S S}$ and $X_{s r}$.

Thus, the final demand of region $r$ will induce impacts on the added value of both $\mathrm{r}$ and $\mathrm{s}$ regions. The total value added when the spillover effect is accounted for by the final product of area $\mathrm{r}$ is: $V_{R} X_{r r}+V_{S} X_{S r}$ and the total value added diffused by the final demand of the region $\mathrm{s}$ is $V_{R} X_{r S}+V_{S} X_{S S}$.

And the total added value of a region is determined:

$$
\begin{aligned}
& V_{R} X_{r r}+V_{S} X_{r s} \\
& V_{R} X_{r s}+V_{S} X_{s r}
\end{aligned}
$$

The ICT sector is grouped and classified according to the OECD's ICT definition (Organisation for Economic Co-operation and Development [OECD], 2009), the International Standard of Industrial Classification (ISIC) (United Nations [UN], 2008) and the Vietnamese understanding. OECD (2009) defined the information economy sector as comprising two industries, ICT sectors (ICT manufacturing and services) and ICT content and media. These sub-sectors bases on and conforms to ISIC ver.4 (UN, 2008). Even so, a lot of controversy about the boundary between the ICT sector and the content and media sector has been shown in internal OECD and UN's documents (see World Bank [WB], 2009). In Vietnam, the Information and Communication is the official sector of the formal statistical system. This sector includes (1) ICT services and (2) ICT content and media (Government Statistics Organization [GSO], 2019); ICT manufacturing was not included. The statistical book "Information and Data on ICT in Vietnam" published annually by the Vietnam Ministry of Information and Communication (see Vietnam Ministry of Information and Communication [MIC], 2019) includes all three sub-sectors into the ICT sector. In this article, the ICT sector is understood in a broad sense. ICT is divided into three sectors: (1) ICT manufacturing sector produces electronics, computer, and peripheral components, telecommunications devices, consumer electronics, instruments and appliances for measuring, checking, testing and navigating; (2) ICT service sector includes the wholesaling of 
computers, electronics, components, software applications, software services, telecommunications services, postal services, information processing services, computers and telecommunications equipment repair services and other information services; and (3) ICT media and content sector includes publishing, film, broadcasting, recording and other information activities.

For analysis, sectors of the IO tables are grouped into 27 broader sectors as shown in Table 1 . The criteria used for sectorial consolidation include: (1) the list of 19 official sectors published by the General Statistics Office of Vietnam (GSO, 2010; 2015) and the definition of ICT sector of Vietnam Ministry of Telecommunication and Communication; (2) the international definition of the ICT sector, i.e. the OECD's definition and ISIC (OECD, 2009; UN, 2008); (3) the potential impact of ICT on each economic sector. Among these 27 sectors, there are 3 sectors (N1, N2, N3) of agriculture, 14 sectors (from N4 to N17) of manufacturing and 10 sectors (from N18 to N27) of services. In these 27 sectors, 3 sectors belong to ICT while 24 others are non-ICT sectors.

The IO tables are of current production prices. The inflation rate of the ICT sector is lower than those of many other sectors in the economy (GSO, 2019). If this factor is considered, the impact of ICT may be higher. However, due to the lack of sufficient inflation rate data for all sectors, this paper analyses the available IO tables.

Table 1. List of 27 grouped sectors of the Vietnamese economy

\begin{tabular}{llll}
\hline Sector & Description & Sector & Description \\
\hline N1 & Agriculture & N15 & Other manufacturing and processing products \\
N2 & Forestry & N16 & Electricity and water \\
N3 & Fishing & N17 & Construction \\
N4 & Metal ore and mineral products & N18 & Wholesale and retail trade \\
N5 & Processed foods & N19 & Transportation services \\
N6 & Drinks and cigarettes & N20 & ICT media and content \\
N7 & Textiles and leather products & N21 & ICT services \\
N8 & Wood and paper products & N22 & Finance and Accounting services \\
N9 & Chemical, petroleum, coal, rubber, plastic & N23 & Services of science, business, employment \\
N10 & products & Non-metallic mineral products & Public services \\
N11 & Basic metals and other metal products & N25 & Education services \\
N12 & ICT manufacturing & N26 & Health care services \\
N13 & Machinery, equipment, utensils and their & N27 & Entertainment services and other services \\
N14 & accessories & & \\
\hline
\end{tabular}

Source: Authors' sectors classification

\section{Results}

\subsection{Input and Output Structure of the Vietnam ICT Sectors}

In 2016, the production of ICT sectors accounts for 5.3\% of the total output of 27 sectors across Vietnam's economy. This is a modest output portion compared to some traditional Vietnamese sectors such as agriculture 9\% (N1), processed foods industry $11 \%(\mathrm{~N} 5)$, textiles and leather products $8 \%(\mathrm{~N} 7)$ and chemical, petroleum, coal, rubber, plastic products 10\% (N9). Among the three Vietnam ICT sectors, the ICT manufacturing sector has the highest production proportion. In 2016, the ICT manufacturing sector contributed 3.52\% of the total production output of the economy. The ICT service sector followed in second place. In the last place, the ICT media and content sector contributed relatively low output portion, only $0.27 \%$ in 2016 .

Period 2007-2012 was the period of the fast growth of both the ICT manufacturing and ICT services. Total gross output was 4 and 3.5 times higher in 5 years, respectively. In the ICT manufacturing sector, this growth can be attributed to the significant investment of big names like Intel, Samsung, LG in electronics manufacturing from 2008. For example, in 2017, the total Samsung Vietnam's export accounted for more than 25\% total export of Vietnam. In 
the ICT service sector, the high growth paralleled with time when the telecommunication market opened to competition after a long phase of monopoly. The competition encouraged investment and free forces for development.

Table 2. Gross output share of ICT in Vietnam economy

\begin{tabular}{lccc}
\hline Year & $\mathbf{2 0 0 7}$ & $\mathbf{2 0 1 2}$ & $\mathbf{2 0 1 6}$ \\
\hline ICT manufacturing & $2.78 \%$ & $3.49 \%$ & $3.52 \%$ \\
ICT media and content & $0.29 \%$ & $0.24 \%$ & $0.27 \%$ \\
ICT services & $1.44 \%$ & $1.55 \%$ & $1.46 \%$ \\
Total ICT & $4.50 \%$ & $5.28 \%$ & $5.25 \%$ \\
Total Economy & $100.00 \%$ & $100.00 \%$ & $100.00 \%$ \\
\hline
\end{tabular}

Source: Authors' calculation

Table 3 presents the input structure of Vietnam's ICT sector. The data show that the proportions of added value of the ICT services and ICT media and content sectors are higher than that of ICT manufacturing. In 2016, the proportions of value added in the total output of the ICT service sector and the ICT media and content sector were $35.42 \%$ and $33.04 \%$, respectively. Meanwhile, this figure of the ICT manufacturing sector was $20.76 \%$ in 2016. This is consistent with the fact that Vietnam's ICT manufacturing sector including electronic components products; computers and peripheral devices of computers and production of communication equipment (telephones, fax machines, antennas, and modems) are heavily assembled, depending on imported components and product export, of which and the value added portion is low, meanwhile, the remaining two ICT sectors are services. Another noteworthy point is that the proportion of the value added of ICT sectors in total production output tends to decrease from 2007 to 2016. This is an unexpected signal, showing a level of the higher intermediate production cost of Vietnam's ICT sectors.

Table 3. Input structure of ICT sectors

\begin{tabular}{lcccccc}
\hline Year & \multicolumn{2}{c}{$\mathbf{2 0 0 7}$} & \multicolumn{2}{c}{$\mathbf{2 0 1 2}$} & \multicolumn{2}{c}{$\mathbf{2 0 1 6}$} \\
\hline Sector & $\begin{array}{c}\text { Intermediate } \\
\text { input }\end{array}$ & $\begin{array}{c}\text { Value } \\
\text { added }\end{array}$ & $\begin{array}{c}\text { Intermediate } \\
\text { input }\end{array}$ & $\begin{array}{c}\text { Value } \\
\text { added }\end{array}$ & $\begin{array}{c}\text { Intermediate } \\
\text { input }\end{array}$ & Value added \\
\hline ICT manufacturing & $68.12 \%$ & $31.88 \%$ & $73.75 \%$ & $26.25 \%$ & $79.24 \%$ & $20.76 \%$ \\
ICT media and & $32.48 \%$ & $67.52 \%$ & $57.63 \%$ & $42.37 \%$ & $64.58 \%$ & $35.42 \%$ \\
content & $47.05 \%$ & $52.95 \%$ & $58.80 \%$ & $41.20 \%$ & $66.96 \%$ & $33.04 \%$ \\
ICT services & $52.14 \%$ & $47.86 \%$ & $68.64 \%$ & $31.36 \%$ & $75.08 \%$ & $24.92 \%$ \\
Total ICT & & & & & & \\
\hline
\end{tabular}

Source: Authors' calculation

The output structure of the ICT sectors is shown in Table 4. The total output of each sector is divided into intermediate consumption, final consumption, and export. The proportion of intermediate consumption in the ICT media and content sector's total production output was at 70.33\% in 2016. As such, information services (publishing, newspapers, broadcasting) have served well other sectors, possibly through data input into the production and business process, marketing, and advertising services. It is noteworthy that there's a reverse trend in the output structure of ICT manufacturing from 2007 to 2012 and 2016. Before 2012, the sector mainly served the domestic market while from 2012 on, the sector was export-oriented with an export portion in total demand accounted for 96.96\% and 74.16\% in 2012 and 2016, respectively. Combined with the cost structure of this sector, it can be confirmed the assembling characteristic of the ICT manufacturing sector of Vietnam, mainly depending on the imported components that are then re-exported, and the added value is low. 
Table 4. Output structure of Vietnam ICT sectors

\begin{tabular}{lccc}
\hline Sector & Intermediate demand & Domestic Final demand & Export \\
\hline Year & & 2007 & \\
\hline ICT manufacturing & $47.50 \%$ & $48.03 \%$ & $4.48 \%$ \\
ICT media and content & $20.08 \%$ & $73.82 \%$ & $6.10 \%$ \\
ICT services & $47.11 \%$ & $45.62 \%$ & $7.27 \%$ \\
Total ICT & $45.63 \%$ & $48.90 \%$ & $5.47 \%$ \\
\hline Year & & 2012 & \\
\hline ICT manufacturing & $2.71 \%$ & $0.33 \%$ & $96.96 \%$ \\
ICT media and content & $62.95 \%$ & $27.36 \%$ & $4.69 \%$ \\
ICT services & $39.51 \%$ & $55.78 \%$ & $65.96 \%$ \\
Total ICT & $16.22 \%$ & $17.82 \%$ & \\
\hline Year & & 2016 & $74.16 \%$ \\
\hline ICT manufacturing & $21.45 \%$ & $4.40 \%$ & $7.49 \%$ \\
ICT media and content & $70.33 \%$ & $22.18 \%$ & $4.31 \%$ \\
ICT services & $44.96 \%$ & $50.73 \%$ & $51.34 \%$ \\
Total ICT & $30.47 \%$ & $18.19 \%$ & \\
\hline
\end{tabular}

Source: Authors' calculation

\subsection{Sectors With High ICT Expenditure}

Theories of ICT's economic impact indicate that the important contribution of the ICT sector lies in the spillover effect which reflects on the consumption of ICT products and services of other sectors in the economy. The application of ICT supports other economic sectors to make changes in business processes and business models, contributes to the creation of new products and services, thereby improving the performance of these sectors and the whole economy.

Table 5 presents the nine sectors with the highest ICT expenditure in Vietnam. Besides the three ICT sectors, the remaining 6 sectors, including machinery manufacturing, retail and wholesale, financial and accounting services, business and employment science services, public services, education services, are relatively dynamic, requiring high skilled labours. According to Perez (2004), these leading ICT using sectors support broadening the ICT market in the initial phase and compel other economic sectors to apply ICT in production and business activities.

Table 5. Percentage of ICT expenditure in Intermediate cost of high ICT using sectors in 2016

\begin{tabular}{lcccc}
\hline Sector & $\begin{array}{c}\text { ICT } \\
\text { manufacturing }\end{array}$ & $\begin{array}{c}\text { ICT media } \\
\text { and content }\end{array}$ & ICT services & $\begin{array}{c}\text { Whole ICT } \\
\text { sectors }\end{array}$ \\
\hline ICT manufacturing & $19.55 \%$ & $0.03 \%$ & $0.11 \%$ & $19.68 \%$ \\
ICT media and content & $0.84 \%$ & $19.60 \%$ & $3.12 \%$ & $23.57 \%$ \\
ICT services & $9.76 \%$ & $0.62 \%$ & $34.69 \%$ & $45.08 \%$ \\
Machinery, equipment, utensils and their & $2.10 \%$ & $0.01 \%$ & $0.11 \%$ & $2.22 \%$ \\
accessories & $0.46 \%$ & $0.78 \%$ & $3.02 \%$ & $4.26 \%$ \\
Wholesale and retail trade & $0.18 \%$ & $0.33 \%$ & $2.71 \%$ & $3.22 \%$ \\
Finance and Accounting services & $0.39 \%$ & $8.18 \%$ & $2.79 \%$ & $11.36 \%$ \\
Services of science, business, employment & $0.77 \%$ & $2.14 \%$ & $4.27 \%$ & $7.19 \%$ \\
Public services & $0.70 \%$ & $1.75 \%$ & $2.52 \%$ & $4.96 \%$ \\
Education services & $1.32 \%$ & $1.41 \%$ & $2.16 \%$ & $4.90 \%$ \\
Average of all 27 sectors & & & & \\
\hline
\end{tabular}

Source: Authors' calculation 


\subsection{ICT's Dispersion in the Vietnam Economy}

The dispersion of ICT to other economic sectors is reflected in two aspects. On the supply side, ICT sectors consume products and services of themselves and other economic sectors, thus stimulating production. On the demand side, ICT and other sectors use ICT products and services to produce and create output. These effects are captured in output multiplier (backward linkage), input multiplier (forward linkage) absolutely and power of dispersion and sensitivity for dispersion relatively.

On the supply side, the ICT media and content sector has the best backward linkage. In 2016, the output multiplier of ICT media and content sector reached 2.06 times which indicated that each output unit produced by this sector induced 2.06 units of the output of the whole economy. In the same year, the multipliers of the ICT services and the ICT manufacturing sectors were 1.82 and 1.54, respectively. As such, although the ICT manufacturing sector made a larger proportion of total economic output its domestic production diffusion effect was modest compared to the other two ICT sectors. On the demand side, the ICT services sector showed the best forward linkage. In 2016, one unit change in its inputs led to a 1.58 unit change in the total output of the Vietnam economy. Both output and input multipliers increased from 2012 to 2016, indicating an increasing trend of diffusion effect of ICT sectors in the Vietnam economy.

When compared with other economic sectors, ICT sectors' dispersion effect on the economy was moderate. Only the ICT media and content sector shows consistent higher than the economy average power of dispersion, at 1.08, 1.10 and 1.05 in 2007, 2012 and 2016, respectively, the impact of the remaining two ICT sectors recently did not reach the economy average (power of dispersion less than 1). Moreover, the power of dispersion of ICT sectors tended to decrease over time. This was especially true for ICT manufacturing. In 2007, the power of dispersion and sensitivity for dispersion of this sector were both higher than the average of all sectors. In 2016, these figures decreased substantially to only 0.79 and 0.71 , respectively. This implies that big investment, characterized by high import and export levels of Intel, Samsung, or LG could increase the total output but not benefit the dispersion of the manufacturing sector of Vietnam.

Table 6. ICT backward and forwards linkages

\begin{tabular}{|c|c|c|c|c|}
\hline Sectors & $\mathrm{OM}(\mathrm{BL})$ & Power of dispersion & Input multiplier (FL) & $\begin{array}{l}\text { Sensitivity for } \\
\text { dispersion }\end{array}$ \\
\hline Year & \multicolumn{4}{|c|}{2007} \\
\hline ICT manufacturing & 2.01 & 1.25 & 1.83 & 1.14 \\
\hline ICT media and content & 1.74 & 1.08 & 1.08 & 0.68 \\
\hline ICT services & 1.60 & 1.00 & 1.40 & 0.87 \\
\hline Year & \multicolumn{4}{|c|}{2012} \\
\hline ICT manufacturing & 1.24 & 0.76 & 1.04 & 0.63 \\
\hline ICT media and content & 1.80 & 1.10 & 1.24 & 0.76 \\
\hline ICT services & 1.59 & 0.96 & 1.48 & 0.90 \\
\hline Year & \multicolumn{4}{|c|}{2016} \\
\hline ICT manufacturing & 1.54 & 0.79 & 1.39 & 0.71 \\
\hline ICT media and content & 2.06 & 1.05 & 1.31 & 0.67 \\
\hline ICT services & 1.82 & 0.93 & 1.58 & 0.81 \\
\hline
\end{tabular}

Source: Authors' calculation

\subsection{Value-Added Multiplier and Import Multiplier}

To further clarify the output and input impacts of the ICT sector, it is necessary to consider the value-added multiplier and import multiplier (Table 7). A sector that creates high value added and involves a low level of imports is good for the domestic economy. The data shows that the two sectors of ICT media and content, and ICT services, created more added value than stimulated imports. In 2016, an output unit of ICT media and content generated 0.67 units of added value, while stimulated 0.33 units of the import value of the whole economy. Meanwhile, the ICT manufacturing sector had a reverse structure, that is, 1 unit of production in the ICT manufacturing sector generated 
0.34 units of added value and stimulates 0.66 units of imports. Compared to other economic sectors, the ICT media and content sector and ICT services sector had a higher value-added impact than the economy's average (power of dispersion on VA multiplier is greater than 1). Another note is that although the two sectors of ICT media and content and ICT service contributed more in value added than import stimulation, the trend of increasing import multipliers from 2007 to 2016 proves that these sectors relied more and more on imported inputs rather than those domestically produced.

Table 7. ICT value added multiplier and import multiplier

\begin{tabular}{|c|c|c|c|c|}
\hline Sectors & VA multiplier & $\begin{array}{l}\text { Power of dispersion } \\
\text { on VA multiplier }\end{array}$ & Import multiplier & $\begin{array}{c}\text { Average of } \\
\text { import multiplier }\end{array}$ \\
\hline Year & \multicolumn{4}{|c|}{2007} \\
\hline ICT manufacturing & 0.42 & 0.64 & 0.58 & 1.71 \\
\hline ICT media and content & 0.72 & 1.09 & 0.28 & 0.83 \\
\hline ICT services & 0.81 & 1.22 & 0.19 & 0.57 \\
\hline Year & \multicolumn{4}{|c|}{2012} \\
\hline ICT manufacturing & 0.35 & 0.54 & 0.65 & 1.85 \\
\hline ICT media and content & 0.71 & 1.09 & 0.29 & 0.83 \\
\hline ICT services & 0.66 & 1.01 & 0.34 & 0.98 \\
\hline Year & \multicolumn{4}{|c|}{2016} \\
\hline ICT manufacturing & 0.34 & 0.57 & 0.66 & 1.67 \\
\hline ICT media and content & 0.67 & 1.11 & 0.33 & 0.83 \\
\hline ICT services & 0.58 & 0.96 & 0.42 & 1.06 \\
\hline
\end{tabular}

Source: Authors' calculation

4.5 ICT Sectors Self-sufficiency and the Inter Industrial Relationship Between the ICT and Non-ICT Sectors in the Economy

This section applies the IO inter-sector model to examine the self-sufficiency of ICT sectors as well as inter-sector relationship between ICT sectors and the rest of the Vietnamese economy. The cross-production and cross-consumption effects show these features.

a. Self-sufficiency and the inter-sector relationship between the ICT sector and non-ICT sectors through intermediate production and consumption

The output multiplier impact of the ICT sector is divided into three components: (1) the impact within the sector itself, i.e. the ICT sector consumes its own products as inputs, (2) the impact of an ICT sector to the production of other ICT sectors, i.e. an ICT sector consumes the products of other ICT sectors and (3) the impact of the ICT sector on the production of non-ICT sectors, i.e. the ICT sector consume products of non-ICT sectors.

The data in Table 8 show that the output impact of the ICT sectors was mainly within the sectors itself. For example, in the total output multipliers of 1.82 of ICT service sector in 2016, the intra-sector impact was 1.41 times while the inter-sector impacts were quite low at 0.051 and 0.4 times. Inter-sector relationship among ICT sectors is loose. Linked with high import multipliers of ICT sectors above, it confirms that Vietnam ICT sectors hinge much on imported equipments. Thus, if the ICT media and content sector or the ICT services sector needs hardware equipments and devices, they tend to import instead of using domestic manufacturing products. In contrast, the ICT manufacturing sector rarely uses the services of the other two ICT sectors. The spillover effect to other sectors in the economy of ICT sectors was highest for ICT media and content, demonstrating that the sector used more input from the rest of the economy than the other two sectors. One output unit of this sector stimulates 0.86 output units of non-ICT sectors in the Vietnam economy. 
Table 8. ICT spillover effect

\begin{tabular}{|c|c|c|c|c|}
\hline Sectors & $\begin{array}{l}\text { Total impacts of } \\
\text { multiplier effects } \\
\text { inside ICT sector }\end{array}$ & $\begin{array}{l}\text { Inter-sectoral effects } \\
\text { induced by } \\
\text { production of other } \\
\text { sectors }\end{array}$ & $\begin{array}{l}\text { Spillover effects to } \\
\text { other sectors in } \\
\text { economy }\end{array}$ & $\begin{array}{l}\text { Total output } \\
\text { requirement }\end{array}$ \\
\hline Year & \multicolumn{4}{|c|}{2007} \\
\hline ICT manufacturing & 1.53 & 0.0078 & 0.47 & 2.01 \\
\hline ICT media and content & 1.09 & 0.0065 & 0.64 & 1.74 \\
\hline ICT services & 1.15 & 0.0093 & 0.44 & 1.60 \\
\hline Year & \multicolumn{4}{|c|}{2012} \\
\hline ICT manufacturing & 1.02 & 0.0017 & 0.22 & 1.24 \\
\hline ICT media and content & 1.15 & 0.0044 & 0.65 & 1.80 \\
\hline ICT services & 1.31 & 0.0022 & 0.27 & 1.59 \\
\hline Year & \multicolumn{4}{|c|}{2016} \\
\hline ICT manufacturing & 1.19 & 0.0041 & 0.35 & 1.54 \\
\hline ICT media and content & 1.18 & 0.0088 & 0.86 & 2.06 \\
\hline ICT services & 1.41 & 0.0051 & 0.40 & 1.82 \\
\hline
\end{tabular}

Source: Authors' calculation

b. Self-sufficiency and inter-sector relationship between the ICT sector and non-ICT sectors through final consumption

Another aspect to analyse the self-sufficiency, as well as the inter-sector relationship between the ICT sectors and the rest of the economy is shown through the cross-consumption effect of these two regions. On the one hand, the production of a sector is stimulated by the final consumption of itself. On the other hand, the final consumption of other sectors while stimulating their production also induces the production of ICT sectors since these sectors use ICT products as input.

The results in Table 9 show that the ICT manufacturing sector depends mostly on the final consumption of itself with the total dependency level in 2016 of $95.45 \%$. The impact of final consumption by the non-ICT sectors on the ICT manufacturing sector is negligible, i.e. the non-ICT sectors hardly consume products of the ICT manufacturing sector. In other words, most of the ICT equipment was manufactured for intra-sector usage and export rather than being consumed by non-ICT sectors. This is an undesirable aspect because this means the application of ICT in Vietnam has not stimulated the production of the domestic ICT manufacturing sector.

Production of the remaining two sectors was more dependent on the consumption of non-ICT sectors. In particular, for the ICT media and content sector, the final consumption of non-ICT sectors explained $62.64 \%$ of the sector's output in 2016. This confirms the level of dispersion of these two ICT sectors to the Vietnamese economy.

Table 9. Share of ICT's output created by final demand

\begin{tabular}{|c|c|c|c|}
\hline Sector & $\begin{array}{l}\text { ICT's output induced by } \\
\text { Final demand of ICT }\end{array}$ & $\begin{array}{l}\text { ICT's output induced by Final } \\
\text { demand of the rest of products }\end{array}$ & Total \\
\hline Year & & 2007 & \\
\hline ICT manufacturing & $82.00 \%$ & $18.00 \%$ & $100.00 \%$ \\
\hline ICT media and content & $84.56 \%$ & $15.44 \%$ & $100.00 \%$ \\
\hline ICT services & $59.49 \%$ & $40.51 \%$ & $100.00 \%$ \\
\hline Year & & 2012 & \\
\hline ICT manufacturing & $99.63 \%$ & $0.37 \%$ & $100 \%$ \\
\hline ICT media and content & $46.28 \%$ & $53.72 \%$ & $100 \%$ \\
\hline ICT services & $79.30 \%$ & $20.70 \%$ & $100 \%$ \\
\hline Year & & 2016 & \\
\hline ICT manufacturing & $95.45 \%$ & $4.55 \%$ & $100 \%$ \\
\hline ICT media and content & $37.36 \%$ & $62.64 \%$ & $100 \%$ \\
\hline ICT services & $72.66 \%$ & $27.34 \%$ & $100 \%$ \\
\hline
\end{tabular}

Source: Authors' calculation 


\section{Conclusion}

From the above results, some main conclusion can be drawn for the role of Vietnam ICT in the economy:

Firstly, Vietnam ICT is a small economic sector in terms of contribution to the total GDP of the economy. The hardware manufacturing sector achieved an all-sector-average GDP contribution. The GDP contributions of the ICT service sector and especially the ICT media and content sector are negligible. However, the theories of ICT impact emphasize the ICT sectors' ability to diffuse and stimulate other sectors, so even if being a small economic sector in terms of output, ICT can still be the enabler of the economy.

Secondly, when considering the dispersion effect of Vietnam's ICT sectors through the backward and forward linkages, the impact of the ICT sectors was generally un-prominent in comparison with other sectors, i.e. the spillover effect of the ICT sector has not been well represented in Vietnam. The finding is not surprised in the case of a developing country like Vietnam. Similar results have been identified in some countries such as Iran (Bazzazan, 2009), Croatia (Keček, Hrustek, and Dušak, 2016) and Indonesia (Irawan, 2013). It is a good point that the dispersion effect of ICT sectors increased over time, thus, Vietnam ICT's economic impact can be more solid in the future. ICT stimulated the economy mainly on the supply side, that is, ICT used more products of its own and other economic sectors rather than other sectors used ICT products and services for their development. This is undesirable since theories on the economic impact of ICT always emphasize the ICT application of other sectors to stimulate structure changes and transformations in business.

Thirdly, except for the ICT manufacturing sector, ICT media content and ICT services sectors were not too dependent on imports; however, the trend of dependence on imports rose over 10 years. This is important to note because depending on imports, the enabling effect on the domestic economy of these sectors tends to decrease.

Fourthly, Vietnam ICT manufacturing was a low value added sector. This sector was heavily dependent on imported components and export markets. This is consistent with the fact that the Vietnam ICT manufacturing sector is at a low position in the electronics manufacturing value chain. When considering interactions with other economic sectors, ICT manufacturing was essentially a self-sufficient sector; this sector was less dependent on other sectors in terms of both input and output. The sector's output and value added multipliers were lower than those of other economic sectors in general and the other two ICT sectors in particular. These results reveal that, although the ICT manufacturing sector has significantly greater output than the other two ICT sectors, its spillover effect on the economy was lower. At the current level of Vietnam's economic and labour development, the sector still plays a significant role in terms of job creation and income generation. However, Vietnam ICT manufacturing should be pushed to a higher position in the value chain of electronics manufacturing so that greater contribution and diffusion effect to the economy can be cultivated.

Fifthly, unlike the manufacturing sector that served mainly for export, Vietnam ICT media and content sector mainly served intermediaries to other sectors and the ICT services evenly divided its output for intermediaries and final consumption. This output structure feature was consistent with output and value added multipliers, backward and forward linkages as well as the inter-sector relationship between ICT sectors and non-ICT sectors in the economy. The ICT media and content sector had a higher dispersion effect from the supply side than the average of Vietnam's economic sectors. The cross-impact from the final demand of non-ICT sectors to the output of this sector was also large, so the ICT media and content can be considered as a good economic enabling sector of the Vietnam economy. The ICT services sector has lower economic stimulus and reciprocal impact with non-ICT sectors but is also capable of promoting other non-ICT sectors and the whole economy. However, because both of these two sectors were small, their total impact on the economy was moderate.

Vietnam government has played a critical role in fostering the ICT sector in the past 25 years, bringing ICT from nothing to the position of the well-noted economic sector in the Vietnam economy. Through ICT promotion policies and ICT strategic development plans, the Vietnam government has been active as a pioneer investor and large consumer of ICT sectors of the country. However, the analysis shows that the realized economic impact of ICT on Vietnam has been moderate so far, both directly and indirectly. Even so, this result is not much surprised for a developing country like Vietnam. Since ICT for economic development has become the irreversible trend in the world economy, ICT is also considered a way to narrow the development gap between developing and developed countries, Vietnam should continue its policy of promoting ICT development in the future. The impact analysis above can provide some policy implications for ICT development in Vietnam.

Firstly, if Vietnam pursues the aim of promoting ICT sector as an economic enabler, Vietnam should continue enlarging ICT production and promoting ICT adoption in the economy, paying attention to leading ICT applying sectors since these sectors can compel ICT adoption in the whole economy (Perez 2004). In the present development phase of Vietnam ICT, given limited resources of a developing country, Vietnam should depend more on private 
investment. However, the pioneering role of the government, especially in the field of ICT application is critical for success.

Secondly, the ICT manufacturing can create more jobs and income for labours currently, however, in the future, to gain greater economic benefits, the sector should develop its ability to move upward into a higher position in product value chain to create higher added value for the economy. Vu (2013) emphasizes the trap of low-margin electronics manufacturing of East Asian countries, failing to develop the ability to move into a high-margin sector. The ability is largely related to the competitiveness of domestic electronics manufacturers; however, policy initiatives related to technology transfer can open the way for the sector.

Thirdly, to create economic momentum from the ICT sectors, emphasis should put on the ICT media and content and ICT services sectors. This requires expanding the products and services of these two sectors for economic activities. The creation of innovative information services and content encourages substantial changes in business processes and business models of economic sectors, which transfer to significant development of the whole economy.

\section{References}

Asian Productivity Organization (APO). (2018). APO Productivity Database 2018. Retrieved from https://www.apo-tokyo.org/wedo/productivity-measurement/

Bazzazan, F. (2009). The Importance of ICT in Iran Input-Output Approach. International Conference on Information and Financial Engineering, IEEE Computer Society.

Bresnahan, T. F., \& Trajtenberg, M. (1992). General Purpose Technologies: Engines of Growth?. NBER Working Paper No. 4148.

Daveri, F. (2000). Is growth an Information Technology story in Europe too?. IGIER Working Paper No. 168.

Dosi, G. (1982). Technical Paradigms and Technological Trajectories. Research Policy, 11, 147-162.

Duc, D. T. V., \& Linh, D. H. (2018). Contribution of ICT to the Vietnamese Economy: An Input-Output Analysis. VNU Journal of Science: Economics and Business, 34(5E), 1-17.

Freeman, C. (2005). The ICT Paradigm. In Mansell, R. et al. (Eds.), The Oxford Handbook of Information and Communication Technologies. U.S.: Oxford University Press.

General Statistics Office of Vietnam (GSO). (2010). 2007 Input-Output Table. Hanoi: General Statistics Office of Vietnam.

General Statistics Office of Vietnam (GSO). (2015). 2012 Input-Output Table. Hanoi: General Statistics Office of Vietnam.

General Statistics Office of Vietnam (GSO). (2019). National Account Statistics of Vietnam. Hanoi: General Statistics Office of Vietnam.

Government of Vietnam. (1993). Resolution 49/CP: Development of Information Technology in our Country in the 1990s. Hanoi, 04 August 1993.

Guo, D., \& Hewings, G. J. D. (2001). Comparative Analysis of China's Economic Structures between 1987 and 1997: An Input-output Perspective. The Regional Economics Applications Laboratory (REAL).

Helpman, E. (Eds.) (1998). General Purpose Technologies and Economic Growth. MA, Cambridge: MIT Press.

Heng, T. M., \& Thangavelu, S. M. (2010). Singapore Information Sector: A Study Using Input-Output Tables. Institute of Policy Studies.

Heshmati, A., \& Yang, W. (2006). Contribution of ICT to the Chinese Economic Growth. Ratio Working Papers No. 91.

Indian Ministry of Communications and Information Technology. (2005). India: E-readiness Assessment Report.

International Telecommunication Union (ITU). (2019). ICT Development Index. Retrieved from http://www.itu.int/net4/ITU-D/idi/2017/index.html

Irawan, T. (2013). ICT and Economic Development: Conclusion from IO Analysis for Selected ASEAN Member States. The University of Wuppertal.

Karlsson, E., \& Lijivern, J. (2017). ICT Investment and the Effect on Economic Growth- A Comparative Study across Four Income Groups. International School, Jonkoping University.

Keček, D., Hrustek, N. Z., \& Dušak, V. (2016). Analysis of Multiplier Effects of ICT Sectors: a Croatian Case. Croatian Operational Research Review, 7, 129-145. 
Kegels, C., Van Overbeke. M., \& Van Zandweghe, W. (2002). ICT contribution to economic performance in Belgium: Preliminary evidence. Federal Planning Bureau Working Paper No. 8-02.

Keynes, J. M. (1936). The General Theory of Employment, Interest and Money. Palgrave Macmillan, UK.

Kretschmer, T. (2012). Information and Communication Technologies and Productivity Growth: A Survey of the Literature. OECD Digital Economy Papers, 195.

Lahr, M. L., \& de Mesnard, L. (2004). Bi-proportional Techniques in Input-output Analysis: Table Updating and Structural Analysis. Economic Systems Research, 16, 115-134.

Leontief, W. (1986). Input-Output Economics (2nd ed.). New York: Harvard University Press, Oxford: University Press.

Miller, R. E., \& Blair, P. D. (2009). Input-Output Analysis Foundations and Extensions (2nd ed.). New York: Cambridge University Press.

Ministry of Information and Communication of Vietnam (MIC). (2019). Statistics and Data on Information and Communication of Vietnam. Hanoi: Vietnam.

Miyazawa, K. (1966). An Analysis of the Interdependence Between Service and Goods-producing Sectors. Hitotsubashi Journal of Economics, 12, 10-21.

Niebel, T. (2014). ICT and Economic Growth- Comparing Developing, Emerging and Developed Countries. Discussion Paper, ZEW Centre for European Economic Research.

Organisation for Economic Co-operation and Development (OECD). (2009). Information Economy Product Definitions Based on the Central Product Classification. Geneva: OECD Publishing.

Perez, C. (1983, October). Structural Change and Assimilation of New Technologies in the Economic and Social systems. Future, 357-375.

Perez, C. (2004). Technological Revolutions, Paradigm Shifts, and Socio-Institutional Change. In Erik Cheltenham R. (Ed.), Globalization, Economic Development and Inequality: An Alternative Perspective (pp. 217-242). UK, Northampton, MA, USA: Edward Elgar.

Schreyer, P. (2000). The Contribution of Information and Communication Technology to Output Growth: A Study of the G7 Countries. OECD Science Technology and Industry Working Papers Vol. 2000/2, OECD Publishing.

Sonis, M., \& Hewings, G. (1993). Hierarchies of Regional Sub-structure and Their Multipliers within Input-output Systems: Miyazawa Revisited. Hitotsubashi Journal of Economics, 34, 33-44.

Trinh, B., \& Phong, N. V. (2013). A Short Note on RAS Method. Advances in Management \& Applied Economics, 3(4), 133-137.

Trinh, B., Phong, N. V., \& Quoc, B. (2018). The RAS Method with Random Fixed Points. Journal of Economics and Business, 1(4), 640-646.

United Nations (UN). (2008). International Standard Industrial Classification of all Economic Activities (ISIC), Rev. 4. Department of Economic and Social Affairs, Statistics Division, New York.

Vietnam Communist Party Central Committee. (2000). Directive 58-CT/TW: Accelerating the Use and Development of Information Technology for the Course of Industrialization and Modernization. Hanoi, 17 October 2000.

Vu, M. K. (2013). Information and Communication Technology (ICT) and Singapore's Economic Growth. Information Economics and Policy, 25, 284-300.

World Bank (WB). (2009). Measuring Foreign Direct Investment in the Area of Information and Communication Technology: Deliverable 1-Definition of the ICT Sector, No. 68870 Vol. 2.

World Economic Forum (WEF). (2017). Global Information Technology Report 2016.

\section{Copyrights}

Copyright for this article is retained by the author(s), with first publication rights granted to the journal.

This is an open-access article distributed under the terms and conditions of the Creative Commons Attribution license (http://creativecommons.org/licenses/by/4.0/). 